\title{
Generation of animals allowing the conditional inactivation of the Pax4 gene
}

\author{
Simon Kordowich • Palle Serup • \\ Patrick Collombat $\cdot$ Ahmed Mansouri
}

Received: 7 December 2011 / Accepted: 23 February 2012/Published online: 21 June 2012

(C) The Author(s) 2012. This article is published with open access at Springerlink.com

\begin{abstract}
Pax4 belongs to the paired-box family of transcription factors. The analysis of loss- and gain-offunction mutant animals revealed that this factor plays a crucial role in the endocrine pancreas. Indeed, Pax4 is required for the genesis of insulin-producing betacells. Remarkably, the sole misexpression of Pax4 in glucagon-expressing cells is able to induce their
\end{abstract}

S. Kordowich · A. Mansouri $(\square)$

Department of Molecular Cell Biology, Max-Planck

Institute for Biophysical Chemistry, Am Fassberg,

37077 Göttingen, Germany

e-mail: amansou@gwdg.de

P. Serup

Department of Developmental Biology, Hagedorn

Research Institute, Niels Steensensvej 6, 2820 Gentofte, Denmark

Present Address:

P. Serup

The Danish Stem Cell Center (DanStem), Copenhagen, Denmark

P. Collombat

Diabetes Genetics Team, Inserm, U1091, 06108 Nice,

France

P. Collombat $(\bowtie)$

Université de Nice Sophia-Antipolis, 06108 Nice, France e-mail: Patrick.Collombat@unice.fr

A. Mansouri

Department of Clinical Neurophysiology, University of Göttingen, Robert-Koch Strasse 40, 37075 Göttingen,

Germany regeneration, endow these with beta-cell features, and thereby counter chemically induced diabetes. However, the function of Pax4 in adult endocrine cells remains unclear. Herein, we report the generation of Pax4 conditional knockout mice that will allow the analysis of Pax4 function in mature beta-cells, as well as in the adult central nervous system.

Keywords Beta-cellsPancreas · Insulin · Knockout . Floxed allele $\cdot$ Diabetes

\section{Introduction}

Pax4 is a member of the paired-box-containing family of transcription factors (Mansouri et al. 1996) that has been shown to play a crucial role in the endocrine pancreas (Sosa-Pineda et al. 1997). During pancreas morphogenesis, Pax4 is first detected in the pancreatic epithelium and is later found confined to developing insulin-producing beta-cells, where it is down-regulated perinatally. Cell-lineage studies revealed an expression of Pax4 in all endocrine precursors (Greenwood et al. 2007). Importantly, the analysis of the pancreas of Pax4-deficient animals demonstrated that this factor is an important player in the processes underlying beta-cell genesis (Sosa-Pineda et al. 1997). Indeed, in the absence of Pax4 gene activity, while mutant islets display normal morphology and cell counts, a dramatic beta- and delta-cell loss and a proportional increase in the glucagon-producing 
alpha-cell content are evident (Sosa-Pineda et al. 1997). Further studies have evidenced that, during endocrine cell genesis, Pax4 is involved in the endocrine cell subtype specification. During this process, Pax4 and Arx undergo a reciprocal crossinhibitory interaction to endow endocrine progenitors with beta- and alpha-cell destiny, respectively (Collombat et al. 2003; Collombat et al. 2006). Arx is a homeobox-containing transcription factor that is required for the formation of glucagon-producing alpha-cells (Collombat et al. 2003). Additionally, compound mutants for Pax4 and Arx suffer from a loss of beta- and alpha-cells while the delta-cell content is augmented, revealing that Pax4 is not required for delta-cell genesis (Collombat et al. 2005). Remarkably, the forced expression of Pax4 in glucagon ${ }^{+}$cells
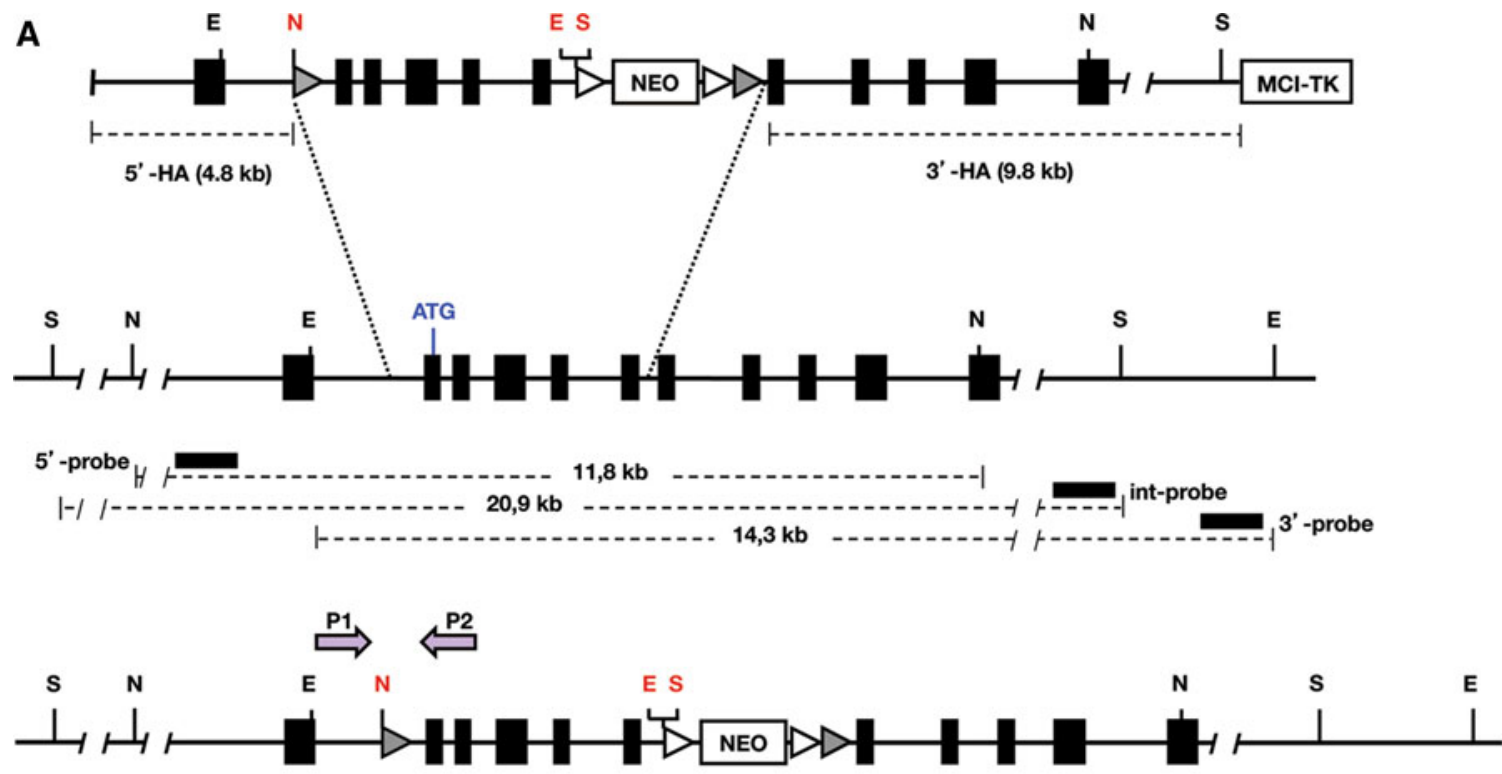

5 '-probe $H F--6,6 \mathrm{~kb}--\mid$

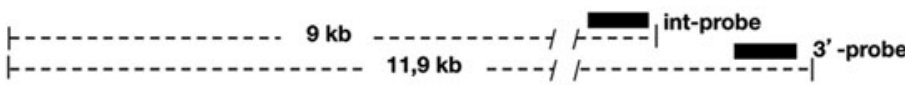

B

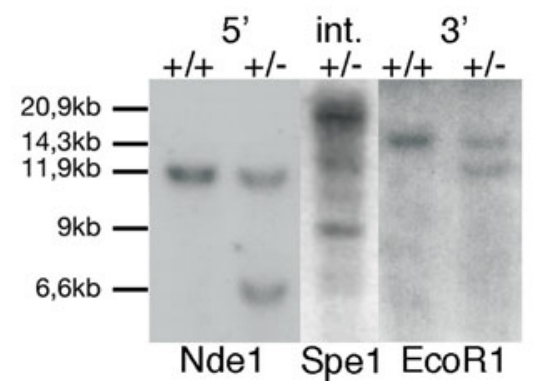

Fig. 1 Targeting construct. The targeting construct was designed and genetic manipulations were performed using recombineering techniques (Copeland et al. 2001). Briefly, a LoxP site was introduced within the first intron and the neomycin resistance cassette carrying the second LoxP site and flanked by Frt sites within the sixth intron. 129 Bac DNA spanning the mouse Pax4 locus was used to isolate the sequences required for the cloning of the targeting construct (A). For negative selection, a MCI-TK cassette was added at the $3^{\prime}$ end to allow selection with gancyclivir (Mansour et al. 1988).

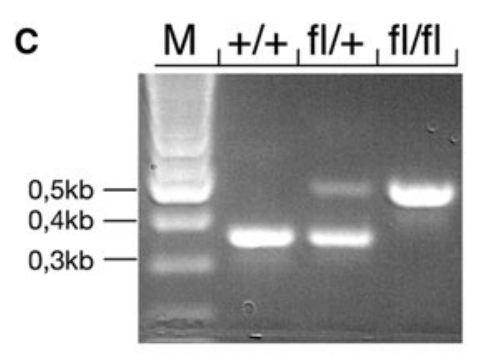

The size of the $5^{\prime}$ and $3^{\prime}$ homology arms (HA) is indicated. Internal and external probes as well as the location of primers for PCR genotyping are also shown. Black boxes indicate exons. White arrowheads represent FRT-sites and dark arrowheads LoxP-sites. B Genomic Southern-blot using 5' and 3' external, as well as internal probe; $\mathrm{N}$ : Nde1; S: Spe1; E: EcoRI, genotype is indicated: $+/+$ wild type; \pm heterozygous for the floxed allele. C Genotyping by PCR; M: molecular weight marker; $+/+$ wild type; fl/+ heterozygous and fl/fl: homozygous 
in vivo was found to induce their regeneration and subsequent conversion into functional beta-like cells that can counter chemically-induced diabetes (Collombat et al. 2009). Hence, Pax4 appears both necessary and sufficient to promote the beta-cell fate/phenotype. However, despite such important roles, the function of this factor in adult beta-cells has hitherto not been addressed. Studies using human and rat islets suggested that it might play an important role in beta-cell proliferation and survival in the adult pancreas (Brun et al. 2004). In addition, the overexpression of Pax4 in adult beta-cells appears to protect insulin-producing cells from apoptosis $(\mathrm{Hu} \mathrm{He}$ et al. 2011). We therefore used an embryonic stem cellmediated gene targeting approach to generate Pax4 conditional knockout mice.

\section{Materials and methods}

Generation of Pax4 conditional knockout mice

Using the recombineering approach (http://recombin eering.ncifcrf.gov/Plasmid.asp), a Pax4 targeting construct was generated. Specifically, one LoxP site was inserted within the first intron, and a neomycin resistance cassette was introduced within the sixth intron (Fig. 1). The neomycin resistance coding sequences are under the control of the PGK promoter. This cassette is flanked by FRT sites and followed by

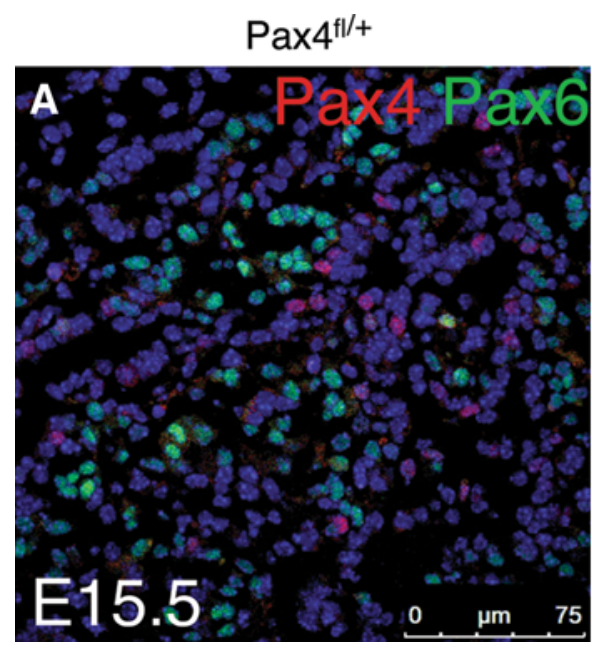

Fig. 2 Inactivation of $\operatorname{Pax} 4$ in animals harboring a Pax4 floxed allele and CMV-Cre transgene. Section of E15.5 pancreas derived from $\operatorname{Pax} 4^{\mathrm{fl} /+}(\mathbf{A})$ and CMV-Cre::Pax4 ${ }^{\mathrm{f} / \mathrm{LacZ}}(\mathbf{B})$ mice one LoxP-site (Fig. 1A). The thymidine kinase gene, used for negative selection, was inserted at the $3^{\prime}$ end of the construct. The targeting construct was electroporated in MPI II ES cells and targeted clones were identified by Southern blot (Fig. 1B). Germ line chimeras were generated by morulae aggregation. Two independent ES cell lines gave germ line transmission. Genotyping reactions were performed using PCR (Primer pair 1: 5'-AGCTCCAGTGAGTTTA GAAACTGCTAGGAGGTG- $3^{\prime}$ and 5'-CTTCCTC AAGTGGGCAACTTGACATCTGGCCCA-3'-WT allele: $358 \mathrm{bp}$; CKO allele: $466 \mathrm{bp}$; Primer pair 2: 5'-GTCTTGAGACTTATGGGTGAAGGCTGACAG GGTCC- $3^{\prime}$ and 5'-CAGTATACATTCGTCTCCTTTA CAGACCCTCACAC-3' -WT allele: 304 bp; P4CKO Allele: $417 \mathrm{bp}$ ). Animal care and experimental use were approved by the Ministry of Agriculture of Low Saxony (LAVES), Germany.

Immunohistochemistry

Embryos were prepared at the indicated time points and pancreatic tissues were isolated and transferred for fixation in $4 \%$ paraformaldehyde overnight. After dehydration, the tissues were embedded in paraffin and $8 \mu \mathrm{m}$ sections were prepared. Following several washes in PBS for $5 \mathrm{~min}$, sections were transferred into blocking solution consisting of PBS containing $10 \%$ fetal calf serum for $1 \mathrm{~h}$. Primary antibodies were diluted in the same blocking solution and incubated

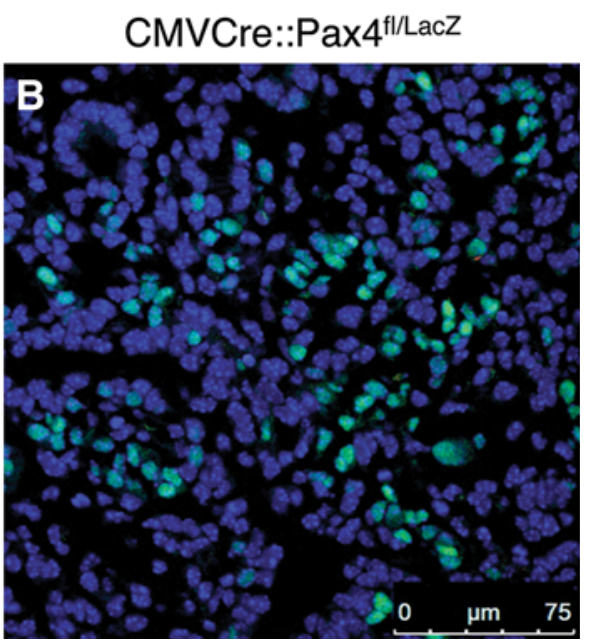

stained for Pax4 (red) and Pax6 (green). In CMVCre::Pax4 f/LacZ mutants, the expression of Pax4 is clearly abolished (B) 

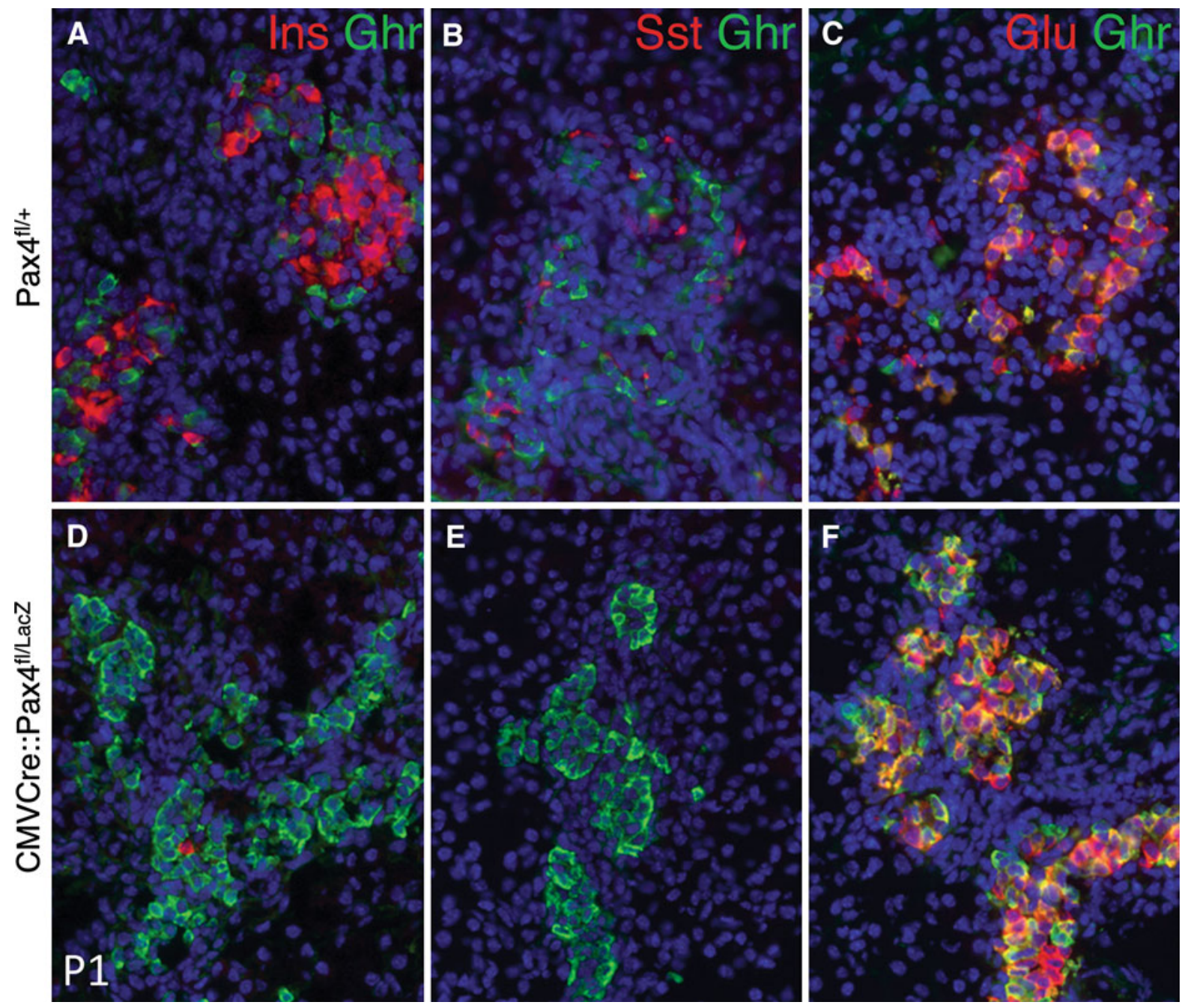

Fig. 3 Inactivation of Pax4 using the floxed Pax4 allele recapitulates the phenotype reported for Pax4 knockout (LacZ knock-in). Immunohistochemical analysis of P1 pancreata derived from Pax $4{ }^{\mathrm{fl} /+}$ and CMV-Cre::Pax $4{ }^{\mathrm{fl} / \mathrm{LacZ}}$ mice for the pancreatic hormones. Mutant pancreata lack insulin- and

overnight at $4{ }^{\circ} \mathrm{C}$. Following washes in PBS, the slides were treated for $1 \mathrm{~h}$ with the corresponding secondary antibodies diluted into PBS containing $10 \%$ fetal calf serum. Slides were then rinsed with PBS, mounted with DAPI, and analyzed by fluorescence microscopy. Primary antibodies used: mouse anti Pax6 (Developmental Studies Hybridoma Bank, dshb@uiowa.edu 1:50), Rabbit anti Pax4 (1:500), kindly provided by Dr. Sosa-Pineda (Collombat et al. 2009); guinea pig anti insulin (1:1000, Dako), mouse anti glucagon (1:1000, abcam), rabbit anti somatostatin (1:600, Dako), rabbit anti ghrelin (1:1000, Millipore), goat somatostatin-producing delta-cells, while the content of alphacells is proportionally increased. Also, the number of ghrelinpositive cells is dramatically augmented. These alterations in hormone expression recapitulate the phenotype previously described for Pax4 knockout mice (Sosa-Pineda 2004)

anti ghrelin (1:50, Santa Cruz). The secondary antibodies (1/1000, Molecular Probes) used : 594-alexa anti-mouse, 488-alexa anti-mouse, 594-alexa antirabbit, 488-alexa anti-rabbit, 594-alexa anti-guinea pig, and 488-alexa anti-guinea pig, 594-alexa antigoat, and 488-alexa anti-goat.

\section{Results and discussion}

A targeting construct was designed and recombineering techniques used to introduce one LoxP site within 
the first intron and a second LoxP site within the sixth intron of the Pax4 gene. As depicted in Fig. 1A, the second LoxP site is integrated into the $3^{\prime}$ end of the neomycin resistance gene, which is flanked by FRT sites.

The knockout construct was electroporated into MPI II ES cells and 2-targeted clones were used to generate chimeric animals by morulae aggregation. Mice homozygous for the floxed Pax4 allele were found normal and fertile. This was true for two mouse lines derived from two independent targeting events. Targeting events were confirmed by Southern blot using $5^{\prime}$ and $3^{\prime}$ external probes (Fig. 1B).

Following germ line transmission, the neomycin cassette was removed by crossing the generated Pax4 animals carrying the floxed allele with transgenic mice ubiquitously expressing the Flp recombinase (Dymecki 1996). Homozygous mice derived from two independent Pax4-targeted ES clones for the floxed allele were also normal and fertile.

To determine whether Pax4 could efficiently be inactivated, we subsequently crossed the floxed allelecarrying animals with a transgenic mouse line expressing the Cre recombinase under the control of the ubiquitous CMV (Cytomegalovirus) promoter. This was achieved by crossing previously derived $\mathrm{Pax}^{+/-}$heterozygous mice in which the beta-galactosidase coding sequence had been inserted into the Pax4 locus (Sosa-Pineda et al. 1997), with CMV-Cre animals, to generate CMV-Cre::Pax $4^{+/-}$double transgenic mice. These were further mated with homozygous Pax $4{ }^{\mathrm{f} / \mathrm{fl}}$ animals. Some of the offspring died at birth or few days postpartum. Those animals were genotyped as CMV-Cre::Pax $4{ }^{\mathrm{f} / \mathrm{LacZ}}$. Using immunohistochemistry on pancreas sections of E15.5 embryos, we could demonstrate that in such animals, Pax4 expression had been abolished, confirming its complete inactivation (Fig. 2B).

We then asked whether Pax4 inactivation in CMVCre::Pax $4{ }^{\mathrm{f} / \mathrm{LacZ}}$ mice could recapitulate the phenotypic alterations that were previously described for Pax4 knockout animals using the LacZ knock-in allele (SosaPineda et al. 1997). Sections from newborn (P1) pancreas derived from Pax $4{ }^{\mathrm{fl} /+}$ or CMV-Cre::Pax $4^{\mathrm{f} / \mathrm{LacZ}}$ mice were subjected to immunohistochemistry to assess the expression of endocrine hormones. As shown in Fig. 3, insulin- as well as somatostatin-producing cells were found lacking whereas the alpha-cell content appeared highly augmented in the islets of these animals. Moreover, numerous glucagonexpressing cells were also found positive for the ghrelin hormone. These findings provide evidence that the observed phenotype in CMV-Cre::Pax $4{ }^{\mathrm{f} / \mathrm{LacZ}}$ mice recapitulates the alterations previously described for the endocrine pancreas of Pax4 knockout animals (Sosa-Pineda et al. 1997; Wang et al. 2008).

The reported mice carrying the Pax4 floxed allele therefore represent a powerful tool to study the role of Pax 4 in the adult pancreas, but also in the central nervous system, in tissues such as in the retina or the pineal gland (Rath et al. 2009a; Rath et al. 2009b).

Acknowledgments The authors would like to thank S. Mahsur for excellent ES cell work and U. Franke for the derivation of germ line chimeras, and C. Heuchel, K. Wetzel for excellent care of the mice. The highly professional assistance of T. Schulz is highly acknowledged. The authors were supported by the Max-Planck Society, the Juvenile Diabetes Research Foundation, the European Research Council, the INSERM AVENIR program, the INSERM, the Fondation pour la Recherche Médicale, the Agence Nationale de la Recherche, the Schlumberger Foundation, the Bundesministerium für Bildung und Forschung (BMBF: 01KU0906), Club Isatis, Mr. and Mrs. Olivier Dorato, and the NIH Beta Cell Biology Consortium (DK 072495). The authors also thank NG Copeland, NA Jenkins, and DL Court (Copeland et al. 2001) (http:// recombineering.ncifcrf.gov/Plasmid.asp) for providing us with plasmids, and bacterial strains for the generation of the targeting construct by recombineering technique.

Conflict of interest The authors declare that they have no conflict of interest.

Open Access This article is distributed under the terms of the Creative Commons Attribution License which permits any use, distribution, and reproduction in any medium, provided the original author(s) and the source are credited.

\section{References}

Brun T, Franklin I, St-Onge L, Biason-Lauber A, Schoenle EJ, Wollheim CB, Gauthier BR (2004) The diabetes-linked transcription factor PAX4 promotes $\{$ beta $\}$-cell proliferation and survival in rat and human islets. J Cell Biol 167(6):1123-1135

Collombat P, Mansouri A, Hecksher-Sorensen J, Serup P, Krull J, Gradwohl G, Gruss P (2003) Opposing actions of Arx and Pax4 in endocrine pancreas development. Genes Dev 17(20):2591-2603

Collombat P, Hecksher-Sorensen J, Broccoli V, Krull J, Ponte I, Mundiger T, Smith J, Gruss P, Serup P, Mansouri A (2005) The simultaneous loss of Arx and Pax 4 genes promotes a somatostatin-producing cell fate specification at the expense of the alpha- and beta-cell lineages in the mouse 
endocrine pancreas. Development 132(13):2969-2980. doi: $10.1242 / \mathrm{dev} .01870$

Collombat P, Hecksher-Sorensen J, Serup P, Mansouri A (2006) Specifying pancreatic endocrine cell fates. Mech Dev 123(7):501-512

Collombat P, Xu X, Ravassard P, Sosa-Pineda B, Dussaud S, Billestrup N, Madsen OD, Serup P, Heimberg H, Mansouri A (2009) The ectopic expression of Pax4 in the mouse pancreas converts progenitor cells into alpha and subsequently beta cells. Cell 138(3):449-462. doi:S00928674(09)00639-410.1016/j.cell.2009.05.035

Copeland NG, Jenkins NA, Court DL (2001) Recombineering: a powerful new tool for mouse functional genomics. Nat Rev Genet 2(10):769-779. doi:10.1038/35093556 35093556

Dymecki SM (1996) Flp recombinase promotes site-specific DNA recombination in embryonic stem cells and transgenic mice. Proc Natl Acad Sci U S A 93(12):6191-6196

Hu He KH, Lorenzo PI, Brun T, Jimenez Moreno CM, Aeberhard D, Vallejo Ortega J, Cornu M, Thorel F, Gjinovci A, Thorens B, Herrera PL, Meda P, Wollheim CB, Gauthier BR (2011) In vivo conditional Pax4 overexpression in mature islet beta-cells prevents stress-induced hyperglycemia in mice. Diabetes 60(6):1705-1715. doi:10.2337/ db10-1102

Mansour SL, Thomas KR, Capecchi MR (1988) Disruption of the proto-oncogene int- 2 in mouse embryo-derived stem cells: a general strategy for targeting mutations to non- selectable genes. Nature 336(6197):348-352. doi:10.1038/ $336348 \mathrm{a} 0$

Mansouri A, Hallonet M, Gruss P (1996) Pax genes and their roles in cell differentiation and development. Curr Opin Cell Biol 8(6):851-857

Rath MF, Bailey MJ, Kim JS, Coon SL, Klein DC, Moller M (2009a) Developmental and daily expression of the Pax4 and Pax6 homeobox genes in the rat retina: localization of Pax4 in photoreceptor cells. J Neurochem 108(1):285-294. doi:JNC576510.1111/j.1471-4159.2008.05765.x

Rath MF, Bailey MJ, Kim JS, Ho AK, Gaildrat P, Coon SL, Moller M, Klein DC (2009b) Developmental and diurnal dynamics of Pax4 expression in the mammalian pineal gland: nocturnal down-regulation is mediated by adrenergic-cyclic adenosine $3^{\prime}, 5^{\prime}$-monophosphate signaling. Endocrinology 150(2):803-811. doi:10.1210/en.2008-0882

Sosa-Pineda B (2004) The gene Pax4 is an essential regulator of pancreatic beta-cell development. Mol Cells 18(3): 289-294

Sosa-Pineda B, Chowdhury K, Torres M, Oliver G, Gruss P (1997) The Pax4 gene is essential for differentiation of insulin-producing beta cells in the mammalian pancreas. Nature 386(6623):399-402. doi:10.1038/386399a0

Wang Q, Elghazi L, Martin S, Martins I, Srinivasan RS, Geng X, Sleeman M, Collombat P, Houghton J, Sosa-Pineda B (2008) Ghrelin is a novel target of Pax4 in endocrine progenitors of the pancreas and duodenum. Dev Dyn 237(1):51-61. doi:10.1002/dvdy.21379 